\title{
The Effect of Using Social Media on Academic Performance of Faculty Members during Covid-19 Pandemic
}

\author{
Mohammad Naim Rahim ${ }^{1}, \&$ Mohamad Bilal Ali ${ }^{2}$ \\ ${ }^{1}$ Kunduz University, Kunduz, Afghanistan \\ ${ }^{2}$ Universiti Teknologi Malaysia, Johor Bahru, Malaysia \\ mnaim.rahim@gmail.com
}

\section{ARTICLE HISTORY \\ Received : 2021-01-19 \\ Revised : 2021-05-21 \\ Accepted : 2021-07-29}

\section{KEYWORDS}

Academic Performance Covid-19 Pandemic

Faculty Members

Paradigm-Shift

Social Media

\begin{abstract}
The use of social media has increased in schools and universities due to the new norms of teaching and learning during the Covid-19 pandemic. However, this educational paradigm shift requires further surveys to explore the potentials and restrictions, particularly in the context of Afghanistan. Therefore, a quantitative method and descriptive survey design are adopted to examine the effect of using social media (Facebook, WhatsApp, and Telegram) on the academic performance (Mean Scores of GPA) of Afghanistan faculty members who are pursuing their postgraduate studies at Universiti Teknologi Malaysia (UTM). The participants are $(\mathrm{N}=103$ male and female) who are randomly selected. The data is collected through a structured survey google form. Frequency and percentage statistical analysis, Independent-Samples T-test, and IndependentMeasures ANOVA are performed as data analysis techniques. The results show a large number of WhatsApp users in terms of frequency and percentage among faculty members of Afghanistan who are using social media. The findings also examine that there is no significant difference between the mean scores of GPA in the academic performance of faculty members using different types of social media. In conclusion, the study contributes to establishing an in-depth understanding of the effect of using social media on the academic performance among faculty members based on the new policies of e-learning implementation by the Ministry of Higher Education during the Covid-19 pandemic.
\end{abstract}

\section{Introduction}

One of the main missions of faculty members is to develop their educational capacities besides conducting research and teaching. This issue has received high attention, especially during the Covid19 pandemic and reformation of the universities based on national and international standards. However, universities in Afghanistan have faced a lack of professionals due to limited resources during few decades of civil war in the country, but the emergence of social media, along with facilitating international academic platforms, have also promoted academic performances among faculty members at universities. Indeed, $21^{\text {st }}$ century is the age of intelligence where ICT has restructured educational instructions globally (Rahim, 2019).

On the other hand, these limitations are not only the lack of infrastructure in Afghanistan but also the lack of motivation for the proper use of social media to enhance capacity-building programs at universities. Whereas, traditional approaches of teaching and learning are also intensively substituted with the new technology-integrated teaching and learning schemas in the country, particularly during the Covid-19 pandemic. Therefore, teachers and students are required to fulfill this gap with the potential knowledge and skills of technology. In the meantime, social media integration is accelerated not only in the educational contexts but also in every aspect of humans' life. As a result, social media can also be assorted as one of the factors effecting faculty members' academic performances in Afghanistan universities.

Currently, social media have functioned as alternative e-learning platforms due to limited access to standard e-learning platforms in Afghanistan and have also provided higher education institutions with barriers and opportunities. In addition, it is ultimately difficult for a faculty member to be offline and not to update the status on social media, especially on Facebook. However, these virtual realities have intended the faculty members to keep in touch and update on certain subjects, but the issue is how these social media effect their academic performances. Therefore, if these social interactions are unrelated to the academic activities of the users, it will limit their 
educational performances. As a result, it is important to explore the effect of using social media on the academic performance of faculty members in Afghanistan universities.

According to Kolan and Dzandza (2018), many schools and universities have restricted the use of social media platforms such as Facebook and YouTube within academic campuses. Since social media is expected to be an obstacle to the teaching and learning circumstances (Rahim, 2021). However, studies have also suggested that using blended learning approaches such as e-learning, $21^{\text {st }}$-century learning, and the use of online platforms as effective modules for EFL education in Afghanistan. Hashemi and Kew (2020) stated that blended learning affects each of the integrated skill of the English language positively and it is suggested that using blended learning as one of the 21 st-century skills need to be taken into consideration for the teaching and learning the English language in Afghanistan. Recently, the mission of education is changed, and everything is just a click away. Hence, there is an urgent need for redefining the national educational objectives and establishing new goals that are aligned with the new norms of Covid-19.

In addition, Musawi and Baktash (2021) have added that during the Covid-19 lockdown, while faceto-face learning has been limited and e-learning started, the Ministry of Higher Education of Afghanistan has begun e-learning in public and private universities. Afghanistan's universities used cloud-based applications in e-learning, but these applications are not identified and ranked in the elearning of Afghanistan. In terms of the pedagogical potentials of these applications, social media are revolutionizing education and paving the way for effective ESL and EFL practices in Afghanistan. Blended learning approaches also offer students a wide range of interactive learning activities since it is a double component, integrating face-to-face teaching and learning with technology-generated learning (Rahim, 2019).

Therefore, the current study is aimed to examine the effect of using social media on the academic performance of Afghanistan faculty members during the Covid-19 pandemic and to explore the challenges and potentials of using social media in the context of teaching and learning. This provides an in-depth understanding of the effect of using social media on the academic performance of the faculty members in the higher education of Afghanistan. In addition, it fulfills the research gaps in terms of context and content since there are few studies in the context of Afghanistan (Rahim, 2019; Rahim \& Sandaran, 2020; Rahim, 2021; Hashemi \& Kew, 2020; Musawi \&
Baktash 2021), which are not relating to the focus of this particular study and have been conducted in a different context using different research methods and samples. The study also enriches the body of existing literature by conducting quantitative research and using statistical analysis to achieve the objectives in Afghanistan. It also addresses the following research questions and tests the stated hypothesis at the alpha $(\alpha=0.05)$ level of significance.

RQ1: What are the percentage of Facebook and WhatsApp users among faculty members of Afghanistan?

RQ2: Is there a significant difference between the academic performance of faculty members who use Facebook and those who use WhatsApp?

RQ3: Which social media users, namely Facebook, WhatsApp, and Telegram, have better academic performance?

H0a: There is no significant difference between the academic performance of faculty members who use Facebook and those who use WhatsApp.

H1a: There is a significant difference between the academic performance of faculty members who use Facebook and those who use WhatsApp.

H0b: There is no significant difference in academic performance of faculty members who use Facebook, who use WhatsApp, and those who use Telegram.

H1b: At least, one group of social media users (Facebook, WhatsApp, or Telegram) has a significant difference in academic performance among faculty members.

\section{Literature Review}

\subsection{The Effect of Using Social Media on the Academic Performance}

The Covid-19 pandemic and the advancement of social media such as Facebook, WhatsApp, and Telegram have divided personal and professional life into two different parts of offline and online. In the context of teaching and learning, however, the use of social media is a paradigm shift. In terms of the directions that they are used, the performance of the practitioners might result differently. As East (2016) stated that social media are destructive tools, especially when they create a false impression. Talaue et al. (2018) also indicated that for individuals acquainted with the fast stream of internet life, the truth might appear to be excessively cloudy. They can have a go at it, making it impossible to (restore) it by making imprudent activities. As a result, the academic performance of faculty members during the Covid-19 pandemic might be effected by each of these social 
media platforms differently. Since some of these social platforms might promote and some might demotivate teaching and learning activities.

\subsection{Effect of Using Facebook on the Academic Performance}

When it comes to the effect of using Facebook on academic performance, some of the faculty members stated that Facebook provides access to knowledge and helps lecturers to exchange information quickly during the Covid-19 pandemic (Rahim, 2021). According to González et al. (2016), combining Facebook with the usual teaching and learning conditions of the classrooms makes it possible to break the four classroom walls and to provide students with a platform where they can interact so that their learning can be effectively promoted. Therefore, it is indicated that Facebook improves academic performance and provides a flexible learning platform.

On the other hand, studies stated that the primary use of Facebook is to communicate about everything except teaching and learning activities and that it only distracts teachers and learners from academic performance. Some of the research which has shown a negative relation between the use of Facebook and academic performance (Junco, 2015; and Rahim, 2021) suggests that this relationship is likely mitigated by multitasking. Therefore, the current study is aimed not only to verify whether academic members obtain higher academic performance, become productive, and achieve better performance levels amongst those who have lower use of social media but also to highlight if Facebook can create an improved platform in the field of teaching and learning.

\subsection{Effect of Using WhatsApp on the Academic Performance}

According to Eberechukwu and Queendarline (2018), there is no significant difference between the mean values of the two groups at a post-test level in terms of using WhatsApp to enhance academic performances. Therefore, the study stated that faculty member should always supplement their classroom with WhatsApp group discussions and other social media platforms. Since these social media platforms offer the students anytime and anywhere education (Rahim \& Sandaran, 2021). However, the findings of the studies by (Aina, 2018), indicated that students are experiencing challenges in using WhatsApp for their academic performance. It was also revealed that WhatsApp is not responsible for the student's poor academic performance since learners use WhatsApp to share academic knowledge and information among themselves. Hence, it is indicated that using
WhatsApp is a key to effect differently on the academic performance of teachers and students at schools and universities.

\subsection{Effect of Using Telegram on the Academic Performance}

Telegram is one of the mobile applications which is used in the context of education in most Asian countries currently. It is launched in 2013 by brothers Nikolai and Pavel Durov, the founders of Russia's largest social network, VKontakte (Akobirov, \& Vokhidova, 2018). This mobile Application has effected the academic performance of faculty members in certain ways. According to a study, Telegram, which is widely used as a means of communication by Iranian youth and has affected the teaching and learning environment at schools and universities (Ghaemi \& Golshan, 2017). Similarly, a study by Alahmar (2016) indicated that faculty members have been spending significant time using Telegram for both academic and non-academic purposes. Heidar and Kaviani (2016) also stated that learning through Telegram brings unique pedagogical advantages for EFL learners and it has a significantly positive effect on vocabulary learning.

In brief, social media has improved learning interactions between faculty members and students. It has also facilitated the communication of the correct information, the development of the ideas and the courses. However, some studies have not recommended the use of social media as a tool for teaching and learning. For instance, Abousaber and Oueder (2018), do not recommend the use of social media during the lecturing time since it is considered as an obstacle to the teaching and learning process. According to Mensah and Nizam (2016), social media platforms significantly affect students' academic performance. However, studies have also indicated that there is a positive effect of using Facebook, WhatsApp, and Telegram on the academic performance of learners during the Covid-19 pandemic.

\section{Method}

The study has adopted a quantitative method and descriptive survey design. This research design is considered suitable for the current study since it enables the researchers to generate data through standardized data collection procedures based on highly structured research instrument(s), well-defined research concepts, and related variables.

The study population is all of the full-time faculty members of Afghanistan who are pursuing their postgraduate studies at UTM in Malaysia from 2017 to 2020. A total sample size of $(\mathrm{N}=103$ male and female) 
postgraduate students are randomly selected from the total population of all full-time faculty members.

The data is collected through a structured survey google form which includes the types of social media users (WhatsApp, Facebook, and Telegram) and GPA scores of the respondents. A total of (103) google form links are distributed to collect data on the types of social media used the most and the respondents' scores of GPAs. A total of (3) survey forms were missing while (1) were incompletely filled, leaving the researcher with (99) valid survey forms.

Responses from the survey on the types of social media (Facebook, WhatsApp, Telegram) and scores of the GPA are analyzed using the statistical analysis of frequency and percentage, Independent-Samples Ttest, and Independent Measures ANOVA. Descriptive statistics of frequency and percentages are used in analyzing demographic variables to answer RQ1 while the Independent-Samples T-test is performed to answer RQ2 and to test the stated hypothesis well as the Independent Measures ANOVA is used to answer RQ3 and to test the stated hypothesis at Alpha $(\alpha=$ 0.05) level of significance.

The following Figure 1 indicates the variables' order and their contents. First, GPA contains the values of GPA scores of faculty members. Second, social media includes the values of $1=$ Facebook, 2=WhatsApp, and 3=Telegram.

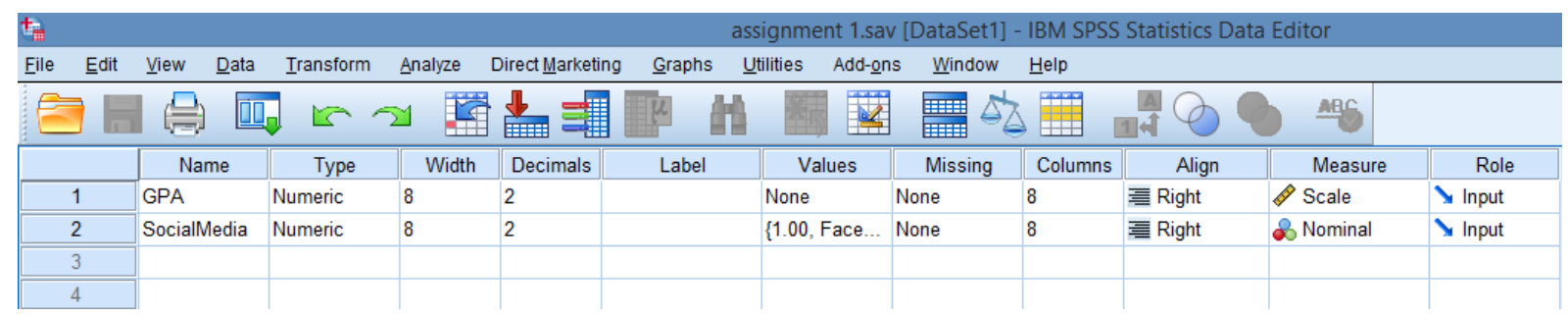

Figure 1. The Variables in SPSS

The values of $1=$ Facebook, 2=WhatsApp, and $3=$ Telegram are the constant of the Social Media users. Also, the GPA scores of the participants during three semesters are evaluated to examine and present the effect of using social media on their academic performance.

\section{Findings and Discussions}

This section presents the results and discusses the findings based on the hypothesis tested using three statistical analyses: 4.1 Simple statistical analysis involving frequencies and percentages of categorical data, 4.2 Independent-Samples T-test, and 4.3 Independent Measures ANOVA.

\subsection{Simple Statistical Analysis Involving Frequencies and Percentages of Categorical Data}

The following Table 1 indicates the frequency and the percentages of Facebook and WhatsApp users among the faculty members of Afghanistan pursuing their post-graduate studies at UTM Malaysia from 2017 to 2020.

Table 1. Frequency and Percentages of Facebook and WhatsApp Users

\begin{tabular}{llllll}
\hline \multicolumn{5}{c}{ SOCIAL MEDIA } \\
\hline \multirow{2}{*}{ Valid } & Frequency & Percent & Valid Percent & Cumulative Percent \\
\cline { 2 - 6 } & WhatsApp & 17 & 51.5 & 51.5 & 51.5 \\
\cline { 2 - 6 } & Facebook & 16 & 48.5 & 48.5 & 100.0 \\
\cline { 2 - 6 } & Total & 33 & 100.0 & 100.0 & \\
\hline
\end{tabular}

The statistic Table 1 shows that how many WhatsApp and Facebook users are there among faculty members in terms of frequency and percentages. Since the study has no missing values, the total number of valid cases in these groups are $(n=33)$ respondents for each variable.

The first column on the left of the list labels the assigned two levels of the variables (1: WhatsApp; 2 :
Facebook). The Frequency column displays the frequency of each score (in this case, category). This shows that from the $(n=33)$ respondents, $(n=17)$ are WhatsApp users, and $(n=16)$ are Facebook users. These frequencies are converted to percentages in the Percent column (51.5\% WhatsApp and $48.5 \%$ Facebook) which shows the percentages of each group of social media users. 
Note: The valid Percent column shows the same values. These would be different if the study had missing data; i.e., this column adjusts the percentages based on missing values. Therefore, the study can conclude that $51.5 \%$ of Afghanistan faculty members at UTM Malaysia are WhatsApp users while $48.5 \%$ are Facebook users.

This result is different from a recent statistic about social media users in Afghanistan. A recent report has indicated that Facebook users are ranked first in the categories of social media users. Napoleon Cat (2020) stated that there are $(3,704,800)$ Facebook users in Afghanistan in January 2020 which has accounted for $9.6 \%$ of its entire population. According to this report, most users are men, $83.9 \%$ who are aged between 25 to 34 . They provide the largest user group $(1,660,000)$ of Facebook users. The highest difference between men and women has ranked between 25 to 34, where men have led by $(1,140,000)$ users.

In addition, the findings indicate that WhatsApp is used mostly for academic purposes. At the same time, the statistics of Facebook users show different statistics of users with the scope of non-academic purposes. According to Rahim and Sandaran (2021), social media is used as e-learning platforms in the higher education institutions of Afghanistan, which have provided students with interactive language learning skills. This study is aligned with the current study's findings, indicating that WhatsApp is used in the academic context for the academic members of Afghanistan in UTM Malaysia. This is also supported by a study that stated the $21^{\text {st }}$-century education is a revolution that encounters information communication technology as a component tool of education aligned with the contexts of teaching and learning (Rahim, 2019). Therefore, the study concludes that WhatsApp is used as a means for teaching and learning.

\subsection{Independent-Samples T-test}

In this section, the mean scores of GPA between two groups of Facebook and WhatsApp users are compared to examine if there is a significant difference in the academic performances between the groups.

Table 2. Case Processing Summary

\begin{tabular}{|c|c|c|c|c|c|c|c|}
\hline & \multirow[b]{3}{*}{ SocialMedia } & \multicolumn{6}{|c|}{ Cases } \\
\hline & & \multicolumn{2}{|c|}{ Valid } & \multicolumn{2}{|c|}{ Missing } & \multicolumn{2}{|c|}{ Total } \\
\hline & & $N$ & Percent & $\mathrm{N}$ & Percent & $\mathrm{N}$ & Percent \\
\hline \multirow[t]{2}{*}{ GPA } & Facebook & 33 & $100.0 \%$ & 0 & $0.0 \%$ & 33 & $100.0 \%$ \\
\hline & WhatsApp & 33 & $100.0 \%$ & 0 & $0.0 \%$ & 33 & $100.0 \%$ \\
\hline
\end{tabular}

Table 2 shows the case processing summary. There is $(n=33)$ for each group of social media users (Facebook and WhatsApp) compared with respondents' GPA scores to examine the mean differences between the groups. Since there are no missing values, both Facebook and WhatsApp groups show $100 \%$ valid cases.

\subsubsection{The Normality Test}

It is one of the assumptions which must be considered when conducting an Independent-Sample T-test. According to Gravetter and Wallnau (2013), if the sample size is more than $(n=30)$, so the data is usually distributed. In the current study, the sample size is $(n=33)$ in each group, so the distribution is normal.

Table 3. Test of Normality

\begin{tabular}{|ll|r|r|r|r|r|r|}
\hline & & \multicolumn{3}{|c|}{ Kolmogorov-Smirnov $^{\mathrm{a}}$} & \multicolumn{3}{|c|}{ Shapiro-Wilk } \\
\cline { 3 - 8 } & SocialMedia & Statistic & \multicolumn{1}{c|}{ df } & \multicolumn{1}{l|}{ Sig. } & \multicolumn{1}{|c|}{ Statistic } & \multicolumn{1}{c|}{ df } & \multicolumn{1}{l|}{ Sig. } \\
\hline GPA & Facebook & .105 & 33 & $.200^{\circ}$ & .956 & 33 & .204 \\
& WhatsApp & .072 & 33 & $.200^{\circ}$ & .983 & 33 & .859 \\
\hline
\end{tabular}

* This is a lower bound of the true significance.

\section{a. Lilliefors Significance Correction}

In Table 3, the Shapiro-Wilk Test of Normality shows that the Sig. Facebook value is $(p=0.204)$, and WhatsApp value is $(p=0.859)$, which are above the Alpha $(\alpha=0.05)$ level of significance. It means that the data is normally distributed in both Facebook and WhatsApp groups. Therefore, the IndependentSample T-test is performed to test the stated hypothesis of the study.

In the following output Table 4 and Table 5 , the group statistics and the results of the IndependentSamples T-test show that the Sig. (2 tailed) value is $(p=0.450)$, which is above the Alpha $(\alpha=0.05)$ level of significance. It means that there is no significant difference in the mean scores of GPAs between the two groups Facebook and WhatsApp users. According to the result, the study fails to reject the null hypothesis. Therefore, it is concluded that there is no significant difference between the academic performance of faculty members who use Facebook and those who use WhatsApp.

Table 4. Group Statistics

\begin{tabular}{|rl|r|r|r|r|}
\hline & SocialMedia & \multicolumn{1}{|c|}{$\mathrm{N}$} & Mean & Std. Deviation & $\begin{array}{c}\text { Std. Error } \\
\text { Mean }\end{array}$ \\
\hline GPA & Facebook & 33 & 3.4055 & .16380 & .02851 \\
& WhatsApp & 33 & 3.3789 & .12030 & .02094 \\
\hline
\end{tabular}


In Table 4, group statistics show that there is no significant difference between the mean scores of GPA among faculty members who use Facebook (M $=3.4055, \mathrm{SD}=0.16380)$ and those who use
WhatsApp $(\mathrm{M}=3.3789, \mathrm{SD}=0.12030)$. The statistics in the columns of means and Std. deviation indicates that they are not statistically significant difference.

Table 5. Result of Independent Samples T-test

\begin{tabular}{|c|c|c|c|c|c|c|c|c|c|}
\hline & \multicolumn{2}{|c|}{$\begin{array}{c}\text { Levene's Test for } \\
\text { Equality of } \\
\text { Variances }\end{array}$} & \multicolumn{7}{|c|}{ t-test for Equality of Means } \\
\hline & \multirow[t]{2}{*}{$\mathrm{F}$} & \multirow[t]{2}{*}{ Sig. } & \multirow[t]{2}{*}{$t$} & \multirow[t]{2}{*}{ df } & \multirow[t]{2}{*}{$\begin{array}{l}\text { Sig. (2- } \\
\text { tailed) }\end{array}$} & \multirow[t]{2}{*}{$\begin{array}{c}\text { Mean } \\
\text { Difference }\end{array}$} & \multirow[t]{2}{*}{$\begin{array}{l}\text { Std. Error } \\
\text { Difference }\end{array}$} & \multicolumn{2}{|c|}{$\begin{array}{l}95 \% \text { Confidence } \\
\text { Interval of the } \\
\text { Difference }\end{array}$} \\
\hline & & & & & & & & Lower & Upper \\
\hline GPA & & & & & & & & & \\
\hline $\begin{array}{c}\text { Equal } \\
\text { variances } \\
\text { assumed }\end{array}$ & 2.763 & 101 & .750 & 64 & .456 & .02655 & .03538 & -04413 & 0.09722 \\
\hline $\begin{array}{c}\text { Equal } \\
\text { variances not } \\
\text { assumed }\end{array}$ & & & .750 & 58.740 & .456 & .02655 & .03538 & -04425 & 0.09734 \\
\hline
\end{tabular}

Note: If the Sig. (2 tailed) value in the Independent Samples T-test table is below $(\alpha=0.05)$ or ( $p<0.05$ ), the null hypothesis is rejected. It means that a significant difference is considered between the two groups.

In this particular study, the results of the Independent Samples Test on the above Table 5 show the conditions; $(\mathrm{t}=0.750),(\mathrm{p}=0.456)$, which is above the alpha $(\alpha=0.05)$ level of significance. Therefore, the study can be concluded that there is no significant difference between the academic performance of faculty members who use Facebook and those who use WhatsApp.

In addition, the finding of the study is aligned with the results of the studies by (Rahim \& Sandaran, 2021; Hashemi \& Kew, 2020; and Musawi \& Baktash, 2021) that social media is used as e-learning, blended learning, and cloud-based applications in universities and schools of Afghanistan during the Covid-19 pandemic. They also indicated that these teaching and learning approaches had provided an interactive learning platform for both teachers and students. These studies have not confirmed the negative effect of using social media on the academic performance of teachers and students. Therefore, the current study also concludes that there is no negative effect of using social media on the academic performance of Afghanistan faculty members during the Covid-19 pandemic.

This is also supported by the results of studies indicating that Facebook as a multi-task platform and WhatsApp as an interactive and conversational messenger have the same effect on the academic performance of the teachers and students (Rahim, 2021; Rahim, 2019; and Rahim \& Sandaran, 2021). A similar study also stated that the relationship between academic performance and GPA is likely mitigated by multitasking (Junco, 2015). As a result, both Facebook and WhatsApp enhance teaching and learning and the use of social media does not affect the GPA scores of teachers and students.

\subsection{Independent Measures ANOVA}

It is performed to comparing the mean scores of three groups. The mean scores of GPAs between faculty members who use Facebook, who use WhatsApp, and those who use Telegram.

Table 6. Case Processing Summary

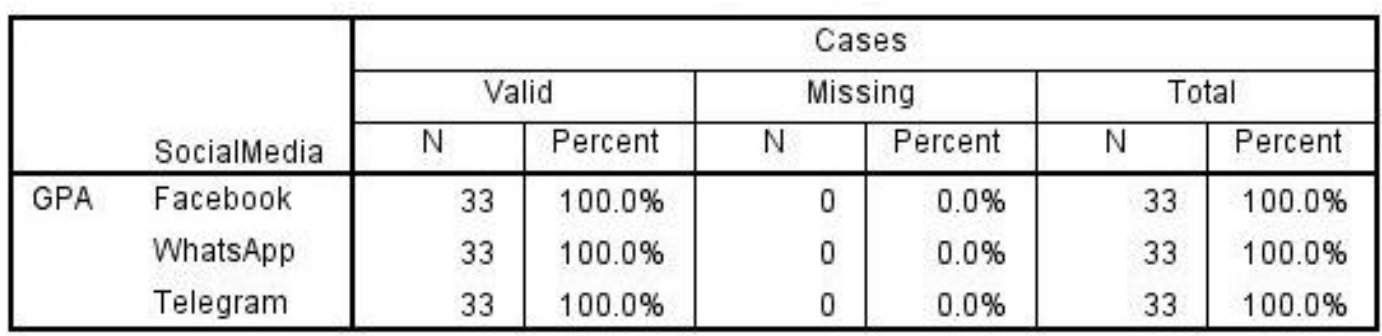


Table 6 shows the case processing summary. There is $(n=33)$ for each group of social media users (Facebook, WhatsApp, and Telegram) compared with the respondents' GPA scores to examine the mean differences between the three groups. Since there are no missing values, all three groups of Facebook, WhatsApp, and Telegram show $100 \%$ valid cases.

\subsubsection{The Normality Test}

In Table 7, the Shapiro-Wilk Test of Normality shows that all three groups of social media users are normally distributed. According to Gravetter and Wallnau (2013), if the sample size is more than $(n=30)$, so the data is assumed to be normally distributed. In this particular study, the sample size is $(n=33)$ for each of the three groups.

Table 7. Test of Normality for Independent Measures ANOVA

\begin{tabular}{|rl|r|r|r|r|r|r|}
\hline & & \multicolumn{3}{|c|}{ Kolmogorov-Smirnov ${ }^{2}$} & \multicolumn{3}{|c|}{ Shapiro-Wilk } \\
\cline { 3 - 8 } & SociallMedia & Statistic & \multicolumn{1}{c|}{ df } & \multicolumn{1}{c|}{ Sig. } & \multicolumn{1}{|c|}{ Statistic } & \multicolumn{1}{c|}{ df } & \multicolumn{1}{c|}{ Sig. } \\
\hline GPA & Facebook & .105 & 33 & $.200^{\circ}$ & .956 & 33 & .204 \\
& WhatsApp & .072 & 33 & $.200^{\circ}$ & .983 & 33 & .859 \\
& Telegram & .095 & 33 & $.200^{\circ}$ & .948 & 33 & .117 \\
\hline
\end{tabular}

*. This is a lower bound of the true significance.

a. Lilliefors Significance Correction

In Table 7, the Shapiro-Wilk Test of Normality shows the Sig. Facebook value is $(p=0.204)$, WhatsApp value is $(p=0.859)$, and Telegram value is $(p=0.117)$, which are above the Alpha $(\alpha=0.05)$ level of significance. It means that the data is normally distributed among all three groups of social media users. Therefore, Independent-Measures ANOVA is performed to test the stated hypothesis.

In the following Table 8, results of IndependentMeasures ANOVA show that the significance value is $(\mathrm{P}=0.752)$, this value is greater than the alpha $(\alpha=0.05)$ level of significance. Therefore, the study fails to reject the null hypothesis.

Table 8. Result of Independent-Measures ANOVA

\begin{tabular}{|l|r|r|r|r|r|}
\hline & \multicolumn{1}{|c|}{$\begin{array}{c}\text { Sum of } \\
\text { Squares }\end{array}$} & \multicolumn{1}{c|}{ df } & Mean Square & \multicolumn{1}{c|}{ F } & \multicolumn{1}{c|}{ Sig. } \\
\hline Between Groups & .012 & 2 & .006 & .285 & .752 \\
Within Groups & 1.957 & 96 & .020 & & \\
Total & 1.969 & 98 & & & \\
\hline
\end{tabular}

Note: if the Sig. Value is less than $(\mathrm{P}<0.05)$, which means that there is a statistically significant difference at least between one of the groups, the null hypothesis is rejected.
According to Table 8, the results of IndependentMeasures ANOVA shows $[\mathrm{F}=(0,285), \mathrm{P}=0.752]$. $\mathrm{P}>0.05$ level of Alpha for the three conditions are $(\mathrm{p}=$ $0.752)$, which is greater than the alpha $(\alpha=0.05)$. Therefore, the study fails to reject the null hypotheses and concludes that there is no significant difference in academic performance of faculty members who use Facebook, who use WhatsApp, and those who use Telegram.

In addition, the finding of the current study is similar to a study by Talaue et al. (2018) stated that all types of social media have significantly expanded the scope of both positive and negative factors of the spiritual and intellectual development of the learners. Another study also indicated that technological tools could be integrated as an effective approach for teaching and learning (Rahim \& Sandaran, 2021). The findings are also supported by a study indicating that the help of mobile technologies and handheld gadgets are a good opportunity to improve the quality and effectiveness of any time and anywhere education (Rahim et al., 2019). However, some studies have highlighted the paradigm shift towards the need for using social media. According to Rahim and Sandaran (2020), the educational system has been transformed and that eLearning provides practical and visual language teaching with any time and anywhere learning opportunities. Therefore, the study concludes that the use of social media (Facebook, WhatsApp, and Telegram) do not affect on GPA scores of faculty members.

\section{Conclusion}

The study highlights that there are many WhatsApp users in terms of frequency and percentage among faculty members of Afghanistan. The findings indicate that WhatsApp is used as a means of academic interaction among students and teachers. The results also show no significant difference between the academic performance of faculty members who use Facebook and those who use WhatsApp. It examines that social media (Facebook, WhatsApp, and Telegram) do not affect the academic performance (GPA scores) of faculty members. The study contributes to the new e-learning policies of the Ministry of Higher Education of Afghanistan. The higher education institutions are recommended to consider the effective potentials of the use of social media as e-learning platforms to address the needs during the Covid-19 pandemic for transforming traditional face-to-face learning into $21^{\text {st }}$-century learning. It is also implicated that the teachers and the students focus on the pedagogical influence of using social media since there is no negative effect of social media on the academic performance of faculty members, particularly during the Covid-19 pandemic. 


\section{Acknowledgement}

For writing this research article, I wish to express my sincere appreciation to professor Dr. Mohammad Bilal Ali, for his encouragement, guidance, critics, and friendship, especially during the statistics course. I am also very thankful to my colleagues and fellow friends at UTM Malaysia for providing insight into this study.

\section{References}

Abousaber, I., \& Oueder, M. (2018). A Study on the Impact of Social Media Usage on Student Academic Performance: University of Tabuk an Example. American Scientific Research Journal for Engineering, Technology, and Sciences, 40(1), 77-88.

Aina, J., F. (2018). Effect of WhatsApp on the Academic Performance of Business Education Students: A Study of Federal College of Education (Technical), (a thesis). Department of Business Education Federal College of Education (Technical), Akoka, Lagos.

Akobirov, F., \& Vokhidova, N. (2018). A New Generation of English Learners-Telegram App Users. Published by Canadian Center of Science and Education, 13(1), 51-62.

Alahmar, A., T. (2016). The Impact of Social Media on the Academic Performance of Second Year Medical Students at College of Medicine, University of Babylon, Iraq. Journal of Medical \& Allied Sciences, 6(2), 77-83.

East, S. (2016). Teens: This is How Social Media Affects Your Brain. CNN. https://edition.cnn.com/2016/07/12/health/social -media-brain/index.html.

Eberechukwu, A., S., \& Queendarline, N., N. (2018). WhatsApp Utilization and Academic Performance of Computer in Education Trainee Teachers in University of Port- Harcourt. International Journal of Education, Learning and Development, 6(5), 15-25.

Ghaemi, F. \& Golshan, N. (2017). The Impact of Telegram as a Social Network on Teaching English Vocabulary among Iranian Intermediate EFL Learners. International Journal of Information and Communication Sciences, 2(5), 86-92.

González, M., R., Gasco, J. \& Llopis, J. (2016). Facebook and Academic Performance: A
Positive Outcome. Anthropologist, 23(1,2), 59-67.

Gravetter, F., J., \& Wallnau, L., B. (2013). Statistics for the Behavioral Sciences. USA. Wadsworth, Cengage Learning.

Hashemi, A., \& Kew, S. N. (2020). The Effects of Using Blended Learning in Teaching and Learning English: A Review of Literature. International Journal of Eurasia Social Sciences, 18(4),173-179.

Heidar, D., M., \& Kaviani, M. (2016). The Social Impact of Telegram as a Social Network on Teaching English vocabulary among Iranian Intermediate EFL Learners. SSYJ, 7(23), 6576.

Junco, R. (2015). Student Class Standing, Facebook Use, and Academic Performance. Journal of Applied Developmental Psychology, 36(1), 18-29.

Kolan, B., \& Dzandza, P. (2018). Effect of Social Media on Academic Performance of Students' in Ghanian Universities: A Case Study of University of Ghana, Legon. Library Philosophy and

Practice (ejournal).1637.https://digitalcommons.unl.edu/l ibphilprac/1637.

Mensah, S., \& Nizam I. (2016). The Impact of Social Media on Students' Academic Performance - A Case of Malaysia Tertiary Institution. International Journal of Education, Learning and Training, 1(1), 1421.

Musawi, S. Z., \& Baktash, J. A. (2021). Identification and Ranking of Cloud-Based Applications in ELearning of Afghanistan: A Case of Public Universities. Elsya : Journal of English Language Studies, 3(2). https://doi.org/10.31849/elsya.v3i2.5796.

NapoleonCat. (2020). Facebook Users in Afghanistan. January 2020. https://napoleoncat.com/stats/facebook-users-inAfghanistan/2020/01.

Rahim, M. N. (2019). The Use of Blended Learning Approach in EFL Education. International Journal of Engineering and Advanced Technology, 8(5C), 1165-1168. https://doi: 10.35940/ijeat.E1163.0585C19.

Rahim, M. N., Hui, Y. K., Johari, M. W., Md Noor, N., \& Abu Bakar, Z. (2019). Mobile Learning Apps for Language Listening Skill. Proceeding of New Academia Learning Innovation (NALI 
2019) Exhibition \& Competition, 147-150. eISBN 978-967- 2171-94-2.

Rahim, M. N., \& Sandaran, S. C. (2020). EFL Teachers' Perceptions of the Barriers and Opportunities for Implementing eLearning at Afghanistan Universities. Universal Journal of Educational Research, 8(11C), 97-104. https://doi.org/10.13189/ujer.2020.082311.

Rahim, M. N. (2021). The Relationship Between the Time Spent on Facebook and GPA Scores of Post-Graduates. International Journal of Multidisciplinary: Applied Business and Education Research, 2(1), 94102.http://ijmaberjournal.org/index.php/ijmaber/ a rticle/view/74.

Rahim, M. N., \& Sandaran, S. C. (2021). The Implementation of E-learning Approach in EFL Education: An Organizational Perspective.

Universe International Journal of Interdisciplinary Research, 1(9), 156-168. http://www.doi-ds.org/doilink/03.2021 98353846/UIJIR.

Rahim, M. N., \& Chandran, S. C. (2021). Investigating EFL Students' Perceptions on Elearning Paradigm-Shift During Covid-19 Pandemic. Elsya: Journal of English Language Studies, 3(1), 56-66. https://doi.org/10.31849/elsya.v3i1.5949.

Rahim, M. N. (2021). Post-Pandemic of Covid-19 and the Need for Transforming Education 5.0 in Afghanistan Higher Education. Utamax: Journal of Ultimate Research and Trends in Education, $3(1)$, 29-39. https://doi.org/10.31849/utamax.v3i1.6166.

Talaue, G., M., AlSaad, A., AlRushaidan, N., AlHugail, A., \& AlFahhad, S. (2018). The Impact of Social Media on Academic Performance of Selected College Students. International Journal of Advanced Information Technology, 8(4), 5. 